\title{
Chemical constituents and pharmacological activities of Mirabilis jalapa-A review
}

\author{
Ali Esmail Al-Snafi 1, Tayseer Ali Talab 1, Wajdi M. Jabbar ${ }^{2}$, and Ali M. Alqahtani ${ }^{2}$ \\ ${ }^{1}$ Dept. of Pharmacology, College of Medicine, University of Thi qar, Iraq. \\ 2 Dept. of Biochemistry, College of Medicine, University of Thi qar, Iraq. \\ ${ }^{3}$ Department of Pharmacology, College of Pharmacy, King Khalid University, Abha, Kingdom of Saudi Arabia.
}

International Journal of Biological and Pharmaceutical Sciences Archive, 2021, 01(02), 034-045

Publication history: Received on 13 January 2021; revised on 01 February 2021; accepted on 03 February 2021

Article DOI: https://doi.org/10.30574/ijbpsa.2021.1.2.0303

\begin{abstract}
Mirabilis jalapa was used traditionally in the treatment of kidney infections, as diuretic, tonic, cathartic, purgative and emetic. The phytochemical screening of the extracts of the leaves and stems of the Mirabilis jalaparevealed the presence of tannins, alkaloids, flavonoids, phenolic compounds, carbohydrates, terpenes, glycosides, saponins, protein, cardiac glycosides, steroids and emodin. The previous pharmacological studies revealed that Mirabilis jalapa possessed wide range of pharmacological and therapeutic effects included antimicrobial, antiparasitic, dermatological, anticancer, antiinflammatory, analgesic, antidiabetic, antihistaminic, immune-modulatory, antispasmodic and many other pharmacological effects. The chemical constituents, nutritional, pharmacological and therapeutic effects ofMirabilis jalapawere discussed in the current review.
\end{abstract}

Keywords: Mirabilis jalapa; constituents; traditional uses; pharmacology; therapeutic; toxicology

\section{Introduction}

Medicinal plant research received much attention as it brings to light the numerous unknown medicinal virtues especially of plant origin which needs evaluation on modern scientific lines such as chemical analysis, pharmacological investigation, pharmacokinetic and pharmacodynamic studies and clinical trials. Mirabilis jalapa was used traditionally in the treatment of kidney infections, as diuretic, tonic, cathartic, purgative and emetic. The phytochemical screening of the extracts of the leaves and stems of the Mirabilis jalaparevealed the presence of tannins, alkaloids, flavonoids, phenolic compounds, carbohydrates, terpenes, glycosides, saponins, protein, cardiac glycosides, steroids and emodin. The previous pharmacological studies revealed that Mirabilis jalapa possessed wide range of pharmacological and therapeutic effects included antimicrobial, antiparasitic, dermatological, anticancer, anti-inflammatory, analgesic, antidiabetic, antihistaminic, immune-modulatory, antispasmodic and many other pharmacological effects. The current review will highlight the chemical constituents, nutritional, pharmacological and therapeutic effects of Mirabilis jalapa.

\subsection{Synonyms}

Jalapa congesta, Jalapa officinalis, Mirabilis ambigua, Mirabilis jalapa var. jalapa, Mirabilis jalapa subsp. lindheimeri, Mirabilis lindheimeri, Mirabilis jalapa var. lindheimeri, Mirabilis pedunculata, Mirabilis planiflora, Mirabilis pubescens, Mirabilis suaveolens, Mirabilis xalapa and Nyctagojalapae [1]. 


\subsection{Taxonomic classification}

Kingdom: Plantae, Subkingdom: Viridiplantae, Infrakingdom: Streptophyta, Superdivision: Embryophyta, Division: Tracheophyta, Subdivision: Spermatophytina, Class: Magnoliopsida, Superorder: Caryophyllanae, Order: Caryophyllales, Family: Nyctaginaceae, Genus: Mirabilis, Species: Mirabilis jalapa [2].

\subsection{Common names}

Arabic: Shab Al-Leil, Al-Shab A-ldhareef, Lala Abbas; Chinese: zimo li; English: beauty-of-the-night, false jalap, fouro'clock; French: belle-de-nuit, Italian: bella di note; Japanese: oshiroi-bana; Persian: Lalehabbasi; Spanish: buenastardes; Swedish: underblomma; Turkish: Akşamsefas [3].

\subsection{Distribution}

There is some disagreement about where it came from originally (tropical America, probably of Peru, Mexico, Chile, or India). Today it was widely distributed throughout the tropics of the world [4-5].

\subsection{Description}

Herbs annual, to $1 \mathrm{~m}$ tall. Roots tuberous, black or black-brown. Stems is erect, branched, glabrous,cylindric, or slightly pubescent, inflated on nodes. Petiole 1-4 cm, leaf, 3-15 $\times 2-9 \mathrm{~cm}$, blade ovate or ovate-triangular, base truncate or cordate, margin entire, apex acuminate. Flowers are several clustered at apex of branches, fragrant; pedicel 1-2 mm. Perianth red, purple, white, yellow, or variegated, tube $2-6 \mathrm{~cm}$, limb $2.5-3 \mathrm{~cm}$ in diameter, opening in late afternoon, closing next morning. Stamens 5, filaments slender, exserted; anther globose. Fruits are globose, black, diameter 5-8 $\mathrm{mm}$, coriaceous, ribbed and plicate. Endosperm white mealy [6-7].

\subsection{Traditional uses}

Leaves were employed for poulticing abscesses and boils. Juices of the leaves were used in treatment of skin allergy, and in earaches in children. Leaves infusion was applied topically to reduce swelling in conditions like bone fractures or twisting. Decoction of Mirabilis Jalapa was used orally as diuretic and in the treatment of kidney infections. Stems were used as tonic. The root of Mirabilis Jalapa was used traditionally as cathartic, purgative, emetic, in the treatment of abnormal accumulation of pus and or liquid and for inflamed and enlarged lymph-nodes [8-11].

The seed powder was used in Zaire externally for infected wounds. In Latin America the roots were used as a purgative and emetic. In Malagasy the plant was used to treat intestinal pains. In South Africa the roots were used as a purgative and the flowers were reputed to emit an odour at night which stupefies or drives away mosquitoes [12].

\subsection{Part used}

Leaves, stems and roots were used medicinally [8-12].

\subsection{Physicochemical characteristics}

Studying of physicochemical parameters of theethanolic extracts of leaf ofMirabilis jalapa showed that the percent $(\mathrm{w} / \mathrm{w})$ of the total ash was 15.15 , acid insoluble ash 4.57 , water soluble ash 3.75 , water soluble extractive value 26.22 , alcohol soluble extractive value 21.81 and ether soluble extractive value $24.94 \%$ [13]. The physicochemical parameter of powder of the whole Mirabilis jalapa were:loss on drying $12.41 \% \pm 0.005$, total ash $11.81 \% \pm 0.001$, water soluble ash $5.06 \% \pm 0.001$, acid insoluble ash $0.41 \% \pm 0.001$, alcohol soluble $11.02 \% \pm 0.007$, water soluble materials $18.63 \% \pm$ 0.007 and ether soluble materials $7.17 \% \pm 0.007$ [14].

The seeds produced $3.0 \%$ oil, of $0.70 \mathrm{~g} / \mathrm{ml}$ density, 26.10 dynes/cm surface tension, and 169.5 millipoise viscosity at $20.5^{\circ} \mathrm{C}$. The determined iodine value was 80 and saponification value 172 [15].

\subsection{Chemical constituents}

The preliminary phytochemical screening of the extracts of the leaves and stems revealed the presence of tannins, alkaloids, flavonoids, phenolic compounds, carbohydrates, terpenes, glycosides, saponins, protein, cardiac glycosides, steroids and emodin [13, 16-21].

(Z)-3-hexenyl acetate, $\beta$-myrcene, (Z)-ocimene, benzyl benzoate, monoterpene (E)- $\beta$-ocimene were the major fragrance component in the plant volatiles. Investigation of the emission of (E)- $\beta$-ocimene, showed an evening-specific maximum (1700-2000 pm), while, the emission of (Z)-3-hexenyl acetate reached its maximum $3 \mathrm{~h}$ later [22]. 
The Mirabilis jalapa leaves extract contained hydrocarbons $17.8 \%$, ketones $18.0 \%$, alcohols $12.1 \%$, sterols $21.2 \%$ and acids 7.0\%, oxymethylanthraquinone, trigonelline, arabinose, galactose and beta-sitosterol [23-24].

The amount of essential elements in Mirabilis jalapa leaves (mg/kg) were: $\mathrm{Mn} 0.42, \mathrm{Fe} \mathrm{5.02,} \mathrm{Zn} \mathrm{1.19,} \mathrm{Pb} 0.04, \mathrm{Cr} 0.14$ and $\mathrm{Cu} 0.067$ and in the stems were: $\mathrm{Pb} 0.13, \mathrm{Zn} \mathrm{1.74,} \mathrm{Cu} 0.58, \mathrm{Cr} 0.13, \mathrm{Mn} 0.72$ and Fe 4.88 [16].

The seeds showed high protein content $(11.0 \pm 0.75 \mathrm{~g} / 100 \mathrm{seed})$. Amino acid analyses of the total protein isolates showed that it consisted of 17 amino acids of which 9 were essential [25].

The analysis of fatty acids constituents of the seed oil showed that they included palmitic acid $18.3 \%$, oleic acid55.3\%, linoleic acid11.5\% and linolenic acid 14.9\% [26].

Many betaxanthins pigments (indicaxanthin, vulgaxanthin-I, miraxanthin-I, -II, -III, -IV, -V and -VI) were identified in the flowers of Mirabilis jalapa [27].

The compounds isolated from the dichloromethane extract of Mirabilis jalapa tubers powder were (\%): 2-butoxyethyl acetate $0.47 ;$ 2,3,5,6-tetramethylpyrazine 0.20;3,6-dioxa-2,7-disilaoctane 1.83; 2-butenedioic acid 0.88; urea 1.52; 3,7dioxa-2,8-disilanonane 2.98; 4-hydroxyquinoline 4.68; pyrimidine 1.09; isosteviol 5.22; n-pentadecanoic acid 0.83; hexadecanoic acid 10.98; octadecan-1-ol 0.83; linoleic acid 10.47; oleic acid 24.74; cyclopentasiloxane 0.90; cholestan16-one 1.08; lukianol 1.29; pregn-5-en-20-one 1.15; dihydrostigmasterol 3.15 and benzene 1.23\%. However, the compounds isolated from the methanol extract of Mirabilis jalapa tubers powder were (\%): 9,12-octadecadienoic acid 0.83; 9,17-octadecadienal 0.18; 2-methyl-Z,Z-3,13-octadecadienol 0.84; 1,5,9,13-tetradecatetraene 0.61; cholest-5-en24-one 10.58; stigmasterol 18.29, $\beta$-sitosterol 60.73 and cholestane $4.32 \%$ [28].

3,3'-Methylenebis(4-hydroxycoumarin); $\quad$ N-D-alpha-phenylyglycine; $\quad$ laminaribiitol 3-(4(dimethylamino)cinnamoyl)-4-hydroxycoumarin were isolated from the Mirabilis jalapawhole plant methanol extract [29].

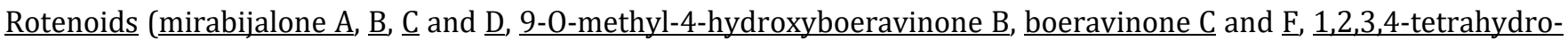
1-methylisoquinoline-7,8-diol), 9-O-methyl- 4-hydroxyboeravinone $\mathrm{B}$, boeravinone $\mathrm{C}$ and $\mathrm{F}$, and 1,2,3,4-tetrahydro -1methylisoquinoline-7,8-diol were identified in the roots of Mirabilis jalapa [30].

The compounds isolated from the roots of the plant were identified as astragaloside II, astragaloside II, astragaloside IV, astragaloside VI, flazin, 4'-hydroxy-2, 3-dihydroflavone 7-beta-D-glucopyranoside, gingerglycolipid A, 3, 4dihydroxybenzaldehyd, p-hydroxybenzaldehyde, beta-sitosterol and daucosterol [31]. The roots of Mirabilis jalapa also contained glycerin monoeicosate, boeravinone C, mirabijalone A, chrysophanol, stigmasterol, and chrysophanol [32].

A fatty acid, 8-hydroxyoctadeca-cis-11,14-dienoic acid was isolated from the seed oil of Mirabilis jalapa [33].

Quantitative analysis showed that Mirabilis Jalapa leaves contained $0.034 \mathrm{mg} / \mathrm{kg}$ alkaloids [16]. The flavonoid content was $4.41 \pm 0.02 \mathrm{mg} /$ gram of the methanolic extract of Mirabilisjalapaaerial parts [34]. The total phenolic contents of the extracts of Mirabilis jalapa tubers was varied from 21.45 to $364.6 \mathrm{mg}$ gallic acid equivalent (GAE)/g dried extract and the total flavonoid from 5.2 to $71.6 \mathrm{mg}$ quercetin/g dried extract, respectively [28]. The total phenolic content and total flavonoid content of the ethyl acetate extract of the seed epicarp were $4.24 \mathrm{mg}$ GAE/g and $0.39 \mathrm{mg}$ RE/g of dry powder weight respectively [35].

The phenolic compounds identified in the extract of Mirabilis jalapa tubers powder were: ferulic acid, procyanidin derivative, ferulic acid derivative, p-coumaryl-ester, Q-3-0-rhamnoside, dicaffeic acid, rutin and pgl-3-0-glucoside [28]. Polyphenolic amide: $\mathrm{N}$-trans-feruloyl 4'-O-methyldopamine was also isolated the methanolic extract of Mirabilis jalapa [36].

\section{Pharmacological effects}

\subsection{Antimicrobial effects}

The antimicrobial effect of ethanolic extract of Mirabilis Jalapa leaves was studied against Gram positive and Gram negative bacteria and against two fungi. The zones of growth inhibition of the ethanolic leaves extract were: 
Staphylococcus aureus $11.1 \mathrm{~mm}$, Salmonella typhi $13.5 \mathrm{~mm}$, Escheichia coli $15.0 \mathrm{~mm}$, Pseudomonas aeruginosa $15.5 \mathrm{~mm}$, Penicilliumnotatum 35.0mm and Rhizopusstolonifer 30mm [16].

$\mathrm{N}$-trans-feruloyl 4'-O-methyldopamine, polyphenolic compound isolated the methanolic extract of Mirabilis jalapa showed moderate activity against multidrug-resistant (MDR) Staphylococcus aureus [36].

Two antimicrobial peptides, designated as Mj-AMP1 and Mj-AMP2, were isolated fromMirabilis jalapa seeds, they exhibited a broad spectrum antifungal activity, they were active against 13 plant pathogenic fungi. Concentrations required for 50\% inhibition of fungal growth vary from 6 to 300 micrograms $/ \mathrm{ml}$ for the first peptide, and from 0.5 to 20 micrograms/ml for the second peptide. Both peptides were also active against two Gram-positive bacteria but showed no effect against Gram-negative bacteria [37].

The aqueous and methanolic seeds powder extracts and their combination (1:2 mixture of the aqueous and methanol extracts) at dilutions of 40, 4, 0.4 and $0.04 \mathrm{mg} / \mathrm{ml}$, were tested for antibacterial effect against Staphylococcus aureus, Streptococcus pyogenes, Escherichia coli, Enterobactersp., Vibrio cholerae, Shigellaflexneriand Salmonella typhi. The aqueous extract possessed good growth inhibition against all the bacteria except Enterobacter sp., while the methanol extract showed good inhibition against all except Staphylococcus aureus. The combination of extracts showed good inhibition of all the bacteria to a dilution of $4 \mathrm{mg} / \mathrm{ml}$, and inhibition of Staphylococcus aureus at $0.4 \mathrm{mg} / \mathrm{ml}$ [12].

The antibacterial activity of the aqueous, ethanol, methanol, chloroform and petroleum ether, leaves extracts were tested for their antibacterial activity against Escherichia coli, Staphylococcus aureus, Streptococcus pneumoniae, Bacillus cereus, Enterococcus faecalis, Pseudomonas aeroginosa, Klebsiellapneumoniae, Lactobacillus acidophilus, Salmonella typhiandShigelladysenteriae. Aqueous, chloroform and petroleum ether extracts displayed the minimal inhibition while all the ethanolic and methanolic extracts showed good antibacterial activity against the selected pathogens (zone of growth inhibition 11-15mm against all the tested bacteria, except against Streptococcus pneumoniae 8mm) [38].

The antimicrobial effects of acetone, chloroform, ethanol and methanol extracts of the leaves of Mirabilis jalapa were investigated against Bacillus subtilis, Escherichia coli, Staphylococcus aureus, Streptococci pneumonia, Aspergillus flavus, Aspergillus fumigatus, Aspergillus niger and Aspergillus terreus. The methanol extract at $500 \mu \mathrm{g} / \mathrm{disc}$ extract exerted the largest zone of growth inhibition $(21 \mathrm{~mm})$ against Staphylococcus aureus and the highest inhibition of fungal radial mycelial growth (97.5\% at 500 $\mathrm{\mu g} / \mathrm{ml}$ medium) against Aspergillusflavus. The methanol extract showed the lowest MIC against Staphylococcus aureus $(39 \mu \mathrm{g} / \mathrm{ml})$ and Aspergillus flavus $(45 \mu \mathrm{g} / \mathrm{ml})[19]$.

The investigation of the antibacterial effects of aqueous and alcoholic Mirabilis jalapa leaves extracts showed that 0.5 $\mathrm{mg} / \mathrm{ml}$ concentration was effective inhibitor of growth of Staphylocoous aureus, Escherichia coli and Proteus mirabilis [18].

The antibacterial potential of the methanolic extract of Mirabilisjalapaaerial parts was examined against Gram positive and Gram negative organisms.The extract displayed significant activity against all the tested microorganisms with MIC of $1 \mathrm{mg} / \mathrm{ml}[34,39]$.

The methanol, acetone, diethyl ether and chloroform extracts of different Mirabilis jalapavarieties were tested for antibacterial activities against Gram negative bacteria (Pseudomonas aeruginosa and Escherichia coli) and Gram positive bacteria (Staphylococcus aureus and Bacillus subtilis). The methanol extracts followed by acetone extracts of all variety showed more potent inhibitory activity than the diethyl ether and chloroform extracts. However the leaf methanolic extract from the white flowered variety showed highest antibacterial activity at $500 \mathrm{mg} / \mathrm{ml}$ followed by the methanolic leaf extracts from pink flowered variety, yellow and orange flowered variety, respectively [40].

The antimicrobial activities of various extracts of Mirabilis jalapa tubers were investigated against Gram-positive (Bacillus cereus, Staphylococcus aureus, Staphylococcus epidermidis, Micrococcus luteus and Enterococcusfaecalis) and Gram-negative (Escherichia coli, Pseudomonas aeruginosa and Klebsiellapneumoniae) bacteria. Water extract was the most effective with minimum inhibitory concentration of $<200 \mu \mathrm{g} / \mathrm{ml}$ against Staphylococcus aureus, Micrococcus luteus, Pseudomonas aeruginosa, Klebsiella pneumoniae, Bacillus cereus and Enterococcus faecalis. Only water extract showed antifungal activity against Aspergillus niger, Fusarium solani, Fusarium oxysporium and Fusarium granularium [28].

The antimicrobial activity of the ethanol, ethyl acetate, chloroform, formaldehyde and distilled water extracts of Mirabilis jalapa leaves was tested against Staphylococcus aureus, Escherichia coli, Bacillus subtilis, Pseudomonas aeruginosa and Candida albicans. The ethanolic leaf extract showed the most potent activity against Staphylococcus aureus $(36 \mathrm{~mm})$, Candida albicans $(29 \mathrm{~mm})$, Bacillus subtilis $(28 \mathrm{~mm})$, Pseudomonas aeruginosa $(27 \mathrm{~mm})$ and Escherichia 
coli (24 mm), followed by water extract against Bacillus subtilis and Staphylococcus aureus (19 and $16 \mathrm{~mm}$, respectively); formaldehyde extracts against Escherichia coli $(19 \mathrm{~mm})$; and chloroform extract against Pseudomonas aeruginosa (18 $\mathrm{mm}$ ) and Candida albicans (14 $\mathrm{mm}$ ) [41].

The petroleum ether, benzene, chloroform, ethyl alcohol and methanol extracts of the leaves of Mirabilis jalapa were examined for antibacterial effect against Gram positive (Staphylococcus aureus, Staphylococcus epidermidisand Bacillus subtilis), Gram negative (Escherichia coli, Pseudomonas aeruginosa andKlebsiella pneumonia) and antifungal potential against Candida albicans. All extracts except petroleum ether extract possessed potent antibacterial and antifungal effects. Methanol extract showed stronger and broader spectrum of microbial activity as compared to other extracts with zones of growth inhibition of 25, 22, 21, 21, 20, 22, 23mm against Staphylococcus aureus, Staphylococcus epidermidis, Bacillus subtilis, Pseudomonas aeruginosa, Klebsiella pneumonia, Escherichia coli and Candida albicans respectively [42].

The aqueous and ethanolic extract of the leaves of white flowered Mirabilis jalapawas screened for antibacterial activities against Staphylococcus aureus, Salmonella typhi, Escherichia coli, Vibrio choleraeand Bacillus subtilis. The ethanolic extract showed highest (with the reference to the activities of tetracycline which was taken as a standard 100\%) inhibition against Salmonella typhi (54.74\%) than Staphylococcus aureus (54\%), Vibrio cholerae (51.95\%), Escherichia coli (51.08) andBacillus subtilis (50\%), while, the aqueous extracts didn't possess antibacterial activity [43].

The antibacterial effect of the ethanolic leaf extract of Mirabilis jalapawas examined against Salmonella typhiand Bacillus cereus. Zones of growth inhibition for the extract at a concentration of $20 \mathrm{ug} / \mathrm{l}$ were $34.33 \pm 1.70 \mathrm{~mm}$ and $51.33 \pm 1.88 \mathrm{~mm}$ against Salmonella typhiand Bacillus cereus, respectively while the zones of growth inhibition of separated bioactive fraction at $3 \mathrm{mg} / \mathrm{ml}$ were $40.33 \pm 1.33 \mathrm{~mm}$ and $40.67 \pm 1.70 \mathrm{~mm}$, against the same microorganisms, respectively [44].

Aqueous, acetone and ethanol extracts of leaves of Mirabilis jalapawere tested for antimicrobial activity in vitro against biofilm and extended spectrum of beta lactamase (ESBL) producing uropathogenicEscherichia coli (UPEC). Ethanol extract of Mirabilisjalapaleaves exhibited the most potent antibacterial activity against all tested biofilm producing UPEC strains, whereas it inhibited only the ESBL producing 2 of 4 UPEC strains [45].

Antibacterial activity of the acetone, ethyl acetate, petroleum ether and ethanol extracts of leaves of Mirabilis jalapa were tested against biofilm producing uropathogenicE. coli (UPEC 1, UPEC17, UPEC 57 and UPEC 82).The acetone extract exhibited a zone of inhibition of 22,20 and $17 \mathrm{~mm}$ respectively against biofilm producing (UPEC 1, UPEC 17 and UPEC 82) strains. The petroleum ether extract exerted a zone of growth inhibition of 18 and $15 \mathrm{~mm}$ respectively against biofilm producing strains UPEC 1 and UPEC 17. The ethyl acetate extract exhibited a zone of inhibition of 20, 19 and 21 $\mathrm{mm}$ respectively against biofilm producing strains UPEC 1 , UPEC 17 and UPEC 82 [13].

Two fractions of the crude extract of from Mirabilis jalapa radix (triterpenoid and flavone) showed antimicrobial activity when tested against Staphylococcus aureus and Candida albicans [46].

A protein isolated from the root and leaf of Mirabilis jalapashowed anti-plant viral activity (potato virus X, potato virus Y, potato leaf roll virus, and potato spindle tuber viroid) comparable to that of the roots and leaves of the original plant [47-51].

The purified protein has been shown to inhibit the mechanical transmission of tomato mosaic virus (TMV) in tobacco, tomato, and pepper plants, and cucumber green mottle mosaic virus in cucumber plants [52].

1,2,3,4-tetrahydro-1-methylisoquinoline-7,8-diol compound, isolated from the root of Mirabilis jalapa showed a 48\% inhibition against HIV-1 reverse transcriptase at $210 \mu \mathrm{g} / \mathrm{ml}[30]$.

The isoflavone and dehydrorotenoid identified in the plant cell culture of Mirabilis jalapa possessed antifungal activity with IC 50 of 25 and 48 microg/ml, respectively, against Candida albicans DSY1024 [53].

\subsection{Antiparasitic effect}

The anthelmintic activity of aerial parts extracts (20\%, 40\%, 60\%, 80\%) of Mirabilis jalapa was studied using Pheretima posthuma as a test worms. The methanolic extract of Mirabilis jalapa caused paralysis in $12.6 \mathrm{~min}$ and death in $13.5 \mathrm{~min}$. Albendazole showed the same effect (at $2.3 \mathrm{~min}$ and $3.24 \mathrm{~min}$ ), respectively [54]. 
The larvicidal activity of crude chloroform, benzene, methanol and ethyl acetate leaf extracts of Mirabilis jalapa was investigated against the larvae of three important vector mosquitoes (An. stephensi, Ae. aegyptiand Cx. Quinquefasciatus). The highest larvicidal activity was possessed by the leaf methanol extract of Mirabilis jalapaagainst Cx. Quinquefasciatus, Ae. aegyptiand An. stephensi, with LC 50 of 84.53, 64.58, 57.55 ppm and LC 90 values of 159.25, 120.28 and 104.20 ppm, respectively. The mortality rate was positively correlated with concentration [55].

\subsection{Antioxidant effect}

The total antioxidant capacity of the acetone, ethyl acetate, petroleum ether and ethanol extracts of leaves of Mirabilis jalapa was measured by the ferric reducing antioxidant power (FRAP) assay. Ethanolic extract showed more antioxidant potential compared to other extracts [13]. DPPH test was used to determine the antioxidant activity of petroleum ether, chloroform and methanol extracts of both the leaves and bark of Mirabilis jalapa. The methanol extract of the plant bark showed antioxidant activity with $\mathrm{IC}_{50}$ value of $598.02 \mu \mathrm{g} / \mathrm{ml}$ compared to ascorbic acid (IC 50 70.985 $\mu \mathrm{g} / \mathrm{ml}$ ) [56]. Two fractions of the crude extract of Mirabilis jalapa radix (triterpenoid and flavone) showed free-radical scavenging activity by using 2,2-diphenyl-1-picrylhydrazyl solution [46].

The antioxidant effect of the methanolic extract of Mirabilis jalapaaerial parts was evaluated using hydrogen peroxide scavenging method and reducing power assay method. The methanolic extract of Mirabilis jalapawas found to show significant reductive property. Mirabilis jalapaextract also caused a moderate dose-dependent inhibition of hyrogenperoxide [57].

The antioxidant activities of various solvent extracts of Mirabilis jalapa tubers were investigated using DPPH and lipid peroxidation assay. The water extract was the most potent antioxidant in all models, followed by methanol extract [58].

The antioxidant potential of aerial (bark and leaves) and the root extracts of Mirabilis jalapa was investigated using ABTS and DPPH assay methods. In DPPH radical scavenging assay, methanolic root extract at the concentration of 500 $\mu \mathrm{g} / \mathrm{ml}$ exhibited 17.53605 $0.1071422 \%$ inhibition (ED $50: 679 \mu \mathrm{g} / \mathrm{ml}$ ), while, the methanolic extract of the aerial parts at the concentration of $500 \mu \mathrm{g} / \mathrm{ml}$ exhibited $17.20884 \pm 0.08971401 \%$ inhibition (ED $50: 3723 \mu \mathrm{g} / \mathrm{ml}$ ). In ABTS free radical scavenging model, the $\mathrm{EC}_{50}$ values were $1249 \mu \mathrm{g} / \mathrm{ml}, 974 \mu \mathrm{g} / \mathrm{ml}, 70.28 \mu \mathrm{g} / \mathrm{ml}$ respectively for methanol root and aerial extracts and quercetin respectively [59].

The ethyl acetate extract of the seed epicarp exhibited high free radical scavenging rate as IC 50 (DPPH and OH assays) were 6.62 and $3.49 \mathrm{mg}$ dry powder weight $/ \mathrm{ml}$ [35].

\subsection{Dermatological effect}

The effects of hydromethanolic extract of tuberous root of Mirabilis jalapa and its terpenoid and flavonoid fractions on skin wound healing were studied using excision wound model on rat. The results indicated that flavonoid caused significant decrease $(\mathrm{P}<0.05)$ in antioxidant enzyme level as compared to control in wound healing process, whereas terpenoid fraction caused significant increase $(\mathrm{P}<0.05)$ in expression of growth factor levels but regeneration and remodeling stages were delayed due to formation of thicker ulcus layer and also there were no hair follicle-like blood capillaries formation which ultimately may lead to formation of hypertrophic scar of wound. The authors concluded that terpenoid fraction prolonged proliferation phase and have tendency to convert the wound into hypertrophic wound [60].

The wound healing activity of the ethanolic extract of the leaves of Mirabilis jalapa (1000mg/kg bw) was investigatedusing excision wound model, incision wound model and dead space wound models in experimentally induced diabetic rats. Mirabilis jalapa extract showed significant wound contraction from $9^{\text {th }}$ to $18^{\text {th }}$ day, significantly increase in wound breaking strength, significantly increase in dry tissue weight, and increased hydroxyproline content compared to normal control and diabetic control animals [61].

\subsection{Anticancer effect}

Brine shrimp lethality bioassay technique was applied to determine the cytotoxic property of petroleum ether, chloroform and methanol extracts of both the leaves and bark of Mirabilis jalapa. The petroleum ether extract of the bark showed significant cytotoxic activity with $\mathrm{LC}_{50}$ value of $8.12 \mu \mathrm{g} / \mathrm{ml}$ compared to vincristine sulphate (LC50 value: $0.33 \mu \mathrm{g} / \mathrm{ml}$ ) [56].

Mirabilis jalapa protein was tested for anticancer effect against different cell lines. It showed cytotoxicity against T47D and SiHa cell lines while it was relatively less cytotoxic to mononuclear cell. It showed more specific cytotoxic activity 
against cancer cell line such as MACF-7, A549, HCT 116, than the normal cell line (Vero). Furthermore it possessed strong apoptotic effects [62-65].

Ribosome-inactivating protein, isolated from the leaves of Mirabilis jalapa was more cytotoxic to HeLa cell-line (LC50 $0.65 \mathrm{mg} / \mathrm{ml})$ than to Raji cell-line $(1.815 \mathrm{mg} / \mathrm{ml})$ after 48 hours' incubation time [66].

A protein fraction with properties like ribosome-inactivating protein (RIP) isolated from the leaves of Mirabilis jalapa possessed cytotoxic effect against T47D and SiHa cell line. The $\mathrm{LC}_{50}$ against T47D cell line and SiHa cell line were $0.36 \mu \mathrm{g} / \mathrm{ml}$ and $5.6 \mu \mathrm{g} / \mathrm{ml}$, respectively. While, it was non toxic against normal cells ( $\mathrm{LC}_{50} \mathrm{of} 21.04 \mu \mathrm{g} / \mathrm{ml}$ ). It produced more cytotoxic activity toward breast and cervical cancer cells (58-fold and 4-fold, respectively) as compared to normal mononuclear cells [67].

\subsection{Antiinflammatory effect}

The total alcoholic extract $(300 \mathrm{mg} / \mathrm{kg})$ and petroleum ether fractions $(200 \mathrm{mg} / \mathrm{kg})$ of leaves of Mirabilis jalapa were screened for its anti-inflammatory activity using carageenan induced rat paw edema and cotton pellet induced granuloma models. The total alcoholic extract and petroleum ether fraction possessed significant anti-inflammatory activity $(\mathrm{P}<0.01)$. They also inhibited granuloma formation significantly $(\mathrm{P}<0.05)$ in cotton pellet granuloma model, they inhibited the increase in number of fibroblasts and synthesis of collagen and mucopolysaccharides during granuloma tissue formation [68].

The anti-inflammatory activity of aqueous leaves extract of Mirabilis jalapa was evaluated using carrageenan and formalin-induced paw edema models in rats. The extract possessed dose dependent anti-inflammatory activity in carrageenan-induced paw edema model, it showed significant $(\mathrm{P}<0.05)$ inhibition of paw oedema, 37.5\% and $54.0 \%$ on $4^{\text {th }}$ hour at the doses of 200 and $400 \mathrm{mg} / \mathrm{kg}$, respectively. In formalin-induced paw edema model, the maximum percentage inhibition in paw edema was $32.9 \%$ and $43.0 \%$ on $4^{\text {th }}$ day at the doses of 200 and $400 \mathrm{mg} / \mathrm{kg}$, respectively [69].

The anti-inflammatory effect of Mirabilis jalapahydro ethanolic flowers extract was investigated in formaldehyde and Complete Freund's adjuvant (CFA) induced arthritis in rats. The extract significantly suppressed the paw edema in both formaldehyde and CFA models $(\mathrm{P}<0.001)$. Body weight, haematological and antioxidant changes in the CFA rats were restored to normal [70].

\subsection{Analgesic effect}

The antinociceptive effect of leaf ethyl acetate fraction from Mirabilis jalapa $(10 \mathrm{mg} / \mathrm{kg}$, orally) was investigated in mice. The extract fraction caused marked reduction in the pain caused by complete Freund's Adjuvant-CFA, surgical incision and partial sciatic nerve ligation. However, the fraction did not alter the paw edema or the increase in the IL- $1 \beta$ levels produced by CFA. The antinociceptive effect of the fraction was reversed by the pre-treatment of animals with the muscarinic receptor antagonists (atropine, $5 \mathrm{mg} / \mathrm{kg}, \mathrm{sc}$ ) or nicotinic receptor antagonists (mecamylamine, $0.001 \mathrm{mg} / \mathrm{kg}$, sc.). The fraction did not alter in vitroacetylcholinesterase activity in blood or spinal cord samples, but it reversed the increase in the acetylcholinesterase activity observed in the spinal cord samples from mice injected with CFA. Furthermore, the fraction did not alter the indicators of liver or kidney lesion [71].

The antinociceptive effect of Mirabilis jalapa crude hydroethanolic leaves and stems extracts was investigated in pain models in mice. The crude hydroethanolic extract of leaves was more potent than the crude extract of stems to inhibit abdominal constrictions induced by acetic acid (ID 50 values of 5.5 (2.3-13.1) and 18.0 (11.3-28.5) $\mathrm{mg} / \mathrm{kg}$, respectively]. Crude hydroethanolic leaves extract also possessed antinociceptive effect in the tail-flick test. Pre-treatment with naloxone did not modify the antinociceptive effect, but co-administration with atropine completely prevented it, which indicated that the antinociceptive effect might depend on the cholinergic system [72].

\subsection{Antidiabetic effect}

The hypoglycemic and hypolipidemic activities of ethanolic extract of Mirabilis jalapa root were studied in normal and streptozotocin induced diabetic mice $(2,4,8 \mathrm{~g} / \mathrm{kg}$, for 14 before and 28 days after induction). Both after and before induction of diabetes, the repeated administration of $4,8 \mathrm{~g} / \mathrm{kg}$ of the extract lowered blood glucose level, improved insulin sensitivity index, lowered serum total cholesterol, triglyceride levels, and decreased triglyceride and increased glycogen content in liver and skeletal muscle. Single administration of the extract $(4$ and $8 \mathrm{~g} / \mathrm{kg}$ ) possessed hypoglycemic effect in oral glucose tolerance test in normal and diabetic mice, but showed no hypoglycemic and hypolipidemic effects on normal and diabetic mice [73]. 
The anti-hyperglycemic effect of hydroethanolic leaf extract of Mirabilis jalapa was investigated in streptozotocin induced diabetic rats. The hydroethanolic leaf extract at the concentration of 200 and $400 \mathrm{mg} / \mathrm{kg}$ showed significant decrease in the levels of glucose, urea, creatinine, aspartate transaminase, alanine transaminase and alkaline Phosphatase in streptozotocin induced diabetic rats [74].

\subsection{Antihistaminic and immune-modulatory effects}

The antihistaminic activity of an ethanol: acetone (1:1) extract of the roots of Mirabilis jalapa was studied using Guinea pig tracheal chain preparation and clonidine-induced mast cell granulation in mice. The extract $(0.5 \mathrm{ml}$ of $100 \mathrm{mg} / \mathrm{ml})$ inhibited histamine-induced Guinea pig tracheal chain contractions non-competitively. The extract (100 or $200 \mathrm{mg} / \mathrm{kg}$, ip) also inhibited milk-induced eosinophilia, albumin-induced paw oedema and protected mast cells against clonidineinduced granulation [75].

The immunomodulatory activity of the methanolic extract (100, 200 and $400 \mathrm{mg} / \mathrm{kg}$ ) of Mirabilis jalapatuber was investigated in mice by using heamagglutination antibody titer, delayed type hypersensitivity, neutrophil adhesion test and carbon clearance test. Oral administration of 200 and $400 \mathrm{mg} / \mathrm{kg}$ of the methanolic extract of Mirabilis jalapasignificantly increased antibody titer, phagocytic index, adhesion of neutrophils and positive hypersensitivity response in mice compared to control group [20].

\subsection{Antispasmodic effect}

The extract of the flowers of Mirabilis jalapa (1-1000 mug/ml) exhibited an inhibitory effect (IC $5018 \pm 0.7 \mathrm{micorg} / \mathrm{ml}$ ) on gut smooth muscle contractility, whereas it stimulated the contraction of rabbit aortic muscle $\left(\mathrm{EC}_{50} 11.60 \pm 0.26\right.$ micorg/ml) in a concentration-dependent manner [76].

\subsection{Other effects}

The aqueous and alcoholic Mirabilis jalapa leaves extracts were examined for their inhibitory effects on hyaluronidase. The percentage of inhibition for aqueous extract was $7.5 \%$, and for alcoholic extract was $6.25 \%$ with respect to control assays [18].

\section{Conclusion}

Mirabilis jalapa contained many bioactive metabolites. It possessed wide range of pharmacological and therapeutic effects included antimicrobial, antiparasitic, dermatological, anticancer, anti-inflammatory, analgesic, antidiabetic, antihistaminic, immune-modulatory, antispasmodic and many other pharmacological effects. The current review highlighted the chemical constituents, traditional uses and pharmacological effects of Mirabilis jalapa.

\section{Compliance with ethical standards}

\section{Acknowledgments}

We acknowledged the dean of Thi qar college of medicine and the dean of Thi qar college of pharmacy for the scientific support.

\section{Disclosure of conflict of interest}

The authors confirm that this paper's content has no conflict of interests.

\section{References}

[1] The plant list, Mirabilis jalapa, http://www.theplantlist.org/tpl1.1/record/kew-2502156

[2] Al-Snafi A. Encyclopedia of chemical constituents and pharmacological effects of Iraqi medicinal plants. Rigi Pubication, 2015.

[3] U. S. national germplasm system, plant Mirabilis jalapa, https://npgsweb.ars-grin.gov/gringlobal/ taxonomydetail. aspx?id=24469

[4] NidavaniRB andMahalakshmi AM. An ethanopharmacological review of four O' clock flower plant, Mirabilis jalapa Linn. Journal of Biological \& Scientific Opinion 2014;2(6):344-348. 
[5] Mirabilis jalapa, Pacific Island Ecosystems at Risk, http://www.hear.org/pier/ species/mirabilis_jalapa.htm

[6] Flora of China, Mirabilis jalapa,http://www.efloras.org/florataxon.aspx? flora_id=2\&taxon_id=200007009

[7] Flora of Pakistan, Mirabilis jalapa,http://www.efloras.org/florataxon.aspx? flora_id=5\&taxon_id=200007009

[8] Chetty KM, Sivagi K and Rao KT. Flowering plants of (Chittoor district, Andra Pradesh, India). Student Offset Printers Trupati 2008:286.

[9] Khurian JC. Plants that heals. 5th ed., Vol. 1, Oriental Watchman Publishing House, Pune 2003; $214-215$.

[10] Watt JM, Breyer-brendwijk MG. The medicinal and poisnous plants of South Africa. E. and S. Livingstone, London 1962:801.

[11] Sharma HK, Chhangte L and Dolui AK. Traditional medicinal plants in Mizoram, India. Fitoterapia 2001; 72:146161.

[12] Kusamba C, Byamana K and Mbuyi WM. Antibacterial activity of Mirabilis jalapa seed powder. J Ethnopharmacol 1991;35(2):197-199.

[13] Selvakumar P, Kaniakumari D and Loganathan V. Phytochemical screening and antioxidant activity of red flowered Mirabilis jalapa leaf in different solvents. International Journal of Pharma and Bio Sciences 2012; 3(4):440-446.

[14] Hanani E, Prastiwi R and Karlina L. Indonesian Mirabilis jalapaLinn: A pharmacognostical and preliminary phytochemical investigations. Pharmacogn J 2017; 9(5):683-688.

[15] Devi YU, Zaidi HR and Saiprakash PK. Composition and characteristics of Mirabilis jalapa seed oil. Fette, Seifen, Anstrichmittel 1983; 85(12):486-487.

[16] Salman SM, Ud Din I, Lutfullah G, Shahwar D, Shah Z , Kamran A, Nawaz S and Ali S.Antimicrobial activities, essential element analysis and preliminary phytochemical analysis of ethanolic extract of Mirabilis jalapa. International Journal of Biosciences 2015; 7(4):186-195.

[17] Kumar S and Fathima E. Mirabilis jalapa: Phytochemical screening and antistress activity of methanolic leaf extract. Journal of Pharmacognosy and Phytochemistry 2017; 6(6):1502-1508.

[18] Mohammed MT. Study of some Mirabilis jalapaL. leaves components and effect of their extracts on growth of pathogenic bacteria. Al- Mustansiriyah J Sci 2012; 23(6):117-124.

[19] Kiran kumar V, Ravi Sankar N, Ramya S, Sahaja RV , Saritha K ,Govinda Reddy K, Naidu NV. Phytochemical screening and antimicrobial activity of the leaf extract of Mirabilis jalapa against pathogenic microorganisms. International Journal of Phytomedicine 2010; 2:402-407.

[20] Shil D, Dash S, Laloo D, Chakraborty J and Das S. Evaluation of immunomodulatory effect of methanolic extract of Mirabilis jalapaL. tuber on mice. RJPBCS 2017; 8(5):49-58.

[21] Devi Sk, Sunny M, Janaipriya N, Nagamani S, Babu TS and Vinupriya S. Pharmacognostical analysis of leaf extracts of Mirabilis jalapaagainst some human pathogenic bacteria. South Asian Journal of Biological Science 2011; 1(1):1-6.

[22] Effmert U, Große J, Röse US, Ehrig F, Kägi R and Piechulla B. Volatile composition, emission pattern, and localization of floral scent emission in Mirabilis jalapa (Nyctaginaceae). Am J Bot 2005; 92(1):2-12.

[23] Behari M, Andhiwal CK and Streibl M. Some chemical constituents of the leaves of Mirabilis jalapa L. Collect Czech ChemCommun 1976; 41:295-298.

[24] Anonymous. The Wealth of India. Vol 4. New Delhi, CSIR, 2003: 135.

[25] Ghosh A, Nayak A and Banerji J. Chemical characterization of seed proteins of Mirabilis jalapa L. (Nyctaginaceae). International Journal of Food Properties 2014; 17(3):559-569.

[26] Patel RG and Patel VS. Studies on Mirabilis jalapa (Four O'clock plant) seed oil. Fette, Seifen, Anstrichmittel 1985; 87(1):7-9.

[27] Piattelli M,Minale L and Nicolaus RA. Pigments of centrospermae-V.: Betaxanthins from Mirabilis jalapa L. Phytochemistry 1965; 4(6):817-823. 
[28] Hajji M, Jarraya R, Lassoued I, Masmoudi O, Damak M and Nasri M. GC/MS and LC/MS analysis, and antioxidant and antimicrobial activities of various solvent extracts from Mirabilis jalapa tubers. Process Biochemistry 2010; 45:1486-1493.

[29] Mahalingam R, Bhirathidasan R, Ambikapathy V and Panneerselvam A. GC-MS determination of bioactive compounds of Mirabilis jalapa. Asian Journal of Plant Science and Research 2012; 2 (3):224-227.

[30] Wang YF, Chen JJ, Yang Y, Zheng YT, Tang SZ, Luo SD, et al. New rotenoids from roots of Mirabilis jalapa.Helvetica ChimicaActa 2002; 85(8):2342-2348.

[31] Lai GF, Luo SD, Cao JX and Wang YF. Studies on chemical constituents from roots of Mirabilis jalapa. ZhongguoZhong Yao ZaZhi 2008; 33(1):42-46.

[32] Jia-le K and De-zhi Z. Chemical constituents of the root of Mirabilis jalapa. Journal of Guangdong College of Pharmacy 2007, http://en.cnki.com.cn/Article_en/ CJFD Total-GDYX200701001.htm

[33] Ahmad MS, Rauf A, Mustafa J, Sheikh and Osman M. An 8-hydroxyoctadeca-cis-11,14-dienoic acid from Mirabilis jalapa seed oil.Phytochemistry 1984; 23(10):2247-2249.

[34] Zachariah S, Viswanad V, Aleykutty NA, Jaykar B and Halima OA. Free radical scavenging and antibacterial activity of Mirabilis jalapa Linn using in vitro models.Asian J Pharm Clin Res 2012; 5(3):115-120.

[35] Wang XH and Dai JT. Anti-oxidant activities of Mirabilis jalapaL seed epicarp extract. Advanced Materials Research 212; 550-553:1768-1772.

[36] Michalet S, Cartier G, David B, Mariotte AM, Dijoux-franca MG, Kaatz GW, et al. N-caffeoylphenalkylamide derivatives as bacterial efflux pump inhibitors. Bioorganic \& Medicinal Chemistry Letters 2007; 17(6):17551758.

[37] Cammue BP, De Bolle MF, Terras FR, Proost P, Van Damme J, Rees SB, Vanderleyden J and Broekaert WF. Isolation and characterization of a novel class of plant antimicrobial peptides form Mirabilis jalapa L seeds. J BiolChem 1992; 267(4):2228-2233.

[38] Sumithra P, Varalakshmi S and Devasena K. Phytochemical analysis and antibacterial activity of Mirabilis jalapaflower against gastrointestinal pathogens. International Journal of Science and Research 2014; 3(12):1167-1170.

[39] Al-Snafi AE. Encyclopedia of chemical constituents and pharmacological effects of Iraqi medicinal plants. Rigi Publication, India, 2015.

[40] Kale DKC and Mukundan U. Phytochemicals analysis and antibacterial activities of genetic variants of Mirabilis jalapa. International Journal of Recent Scientific Research 2015; 6(12):7696-7702.

[41] Muhsina CP and Thamaraiselvi B. Antimicrobial finish for cotton fabric from Mirabilis jalapa leaf extract. IOSR Journal of Environmental Science, Toxicology and Food Technology 2017;11(11):13-17.

[42] Meera R, Devi P, Muthumani P, Kameswari B and Eswarapriya B. In vitro antimicrobial activity of various extracts of Mirabilis jalapa leaves. Int J ChemSci 2010; 8(1):559-564.

[43] Ullah N, Khan MA, Ali H, Altaf N, Ahmad S, Ahmed G and udDin M. Importance of white flowered Mirabilis jalapawith respect to its phytochemical and antimicrobial screening. African Journal of Pharmacy and Pharmacology 2011; 5(24):2694-2697.

[44] Eneji SM, Inuwa HM, Ibrahim S, Ibrahim AB and Abdulfattah A. In vitro assessment of bioactive components of Mirabilis jalapaethanolic extract on clinical isolates of Salmonella typhiand Bacillus cereus. African Journal of Biotechnology 2011; 10(71):16006-16011.

[45] Poovendran P, Vidhya N and Murugan S. Antimicrobial activity of Mirabilis jalapaand Dichrotachyscinereaagainst biofilm and extended spectrum of beta lactamase (ESBL) producing uropathogenicEscherichia coli. African Journal of Microbiology Research 2011; 5(22):3620-3623.

[46] Gogoi J, Nakhuru KS, Policegoudra RS, Chattopadhyay P, Rai AK and Veer V. Isolation and characterization of bioactive components from Mirabilis jalapa L. radix. J Tradit Complement Med 2015;6(1):41-47.

[47] Habuka N, Murakami Y, Noma M, Kudo T and Horikoshi K. Amino acid sequence of Mirabilis antiviral protein, total synthesis of its gene and expression in Escherichia coli. J BiolChem 1989; 264(12):6629-6637.

[48] Ikeda T, Takanami Y, Imaizumi S, Matsumoto T, Mikami Y and Kubo S. Formation of anti-plant viral protein by Mirabilis jalapa L. cells in suspension culture. Plant Cell Rep 1987; 6(3):216-218. 
[49] Wong RN, Ng TB, Chan SH, Dong TX and Yeung HW. Characterization of Mirabilis antiviral protein- a ribosome inactivating protein from Mirabilisjalapa L. BiochemInt 1992;28(4):585-593.

[50] Vivanco JM, Querci M and Salazar LF. Antiviral and antiviroid activity of MAP-containing extracts from Mirabilis jalapa roots. Plant Dis 1999; 83(12):1116-1121.

[51] Takanami Y, Kuwata S, Ikeda and Kubo S. Purification and characterization of the anti-plant viral protein from Mirabilis jalapaL. Ann PhytopatholSocJpn 1990; 56:488-494.

[52] Kubo S, Ikeda T, Imaizumi S, Takanami Y and Mikami Y. A potent plant virus inhibitor found in Mirabilis jalapaL. Ann PhytopatholSocJpn 1990; 56:481-487.

[53] Yang SW, Ubillas R, McAlpine J, Stafford A, Ecker DM, Talbot MK and Rogers B. Three new phenolic compounds from a manipulated plant cell culture, Mirabilis jalapa. J Nat Prod 2001; 64(3):313-317.

[54] Zachariah SM, Jayakar B, Viswanad V and Gopal RV. In vitro anthelmintic activity of aerial parts of Mirabilis jalapa Linn. International Journal of Pharmaceutical Sciences Review and Research 2012; 12:107-110.

[55] Govindarajan M, Ramya A and Sivakumar R. Mosquito larvicidal properties of Mirabilis jalapa (Nyctaginaceae) against Anopheles stephensi, Aedesaegypti\&Culexquinquefasciatus (Diptera: Culicidae). Indian J Med Res 2014;140(3):438-440.

[56] Rumzhum NN, Rahman MM, Islam MS, Chowdhury SA, Sultana B and Parvin MN. Cytotoxicity and antioxidant activity of extractives from Mirabilis jalapa. Stamford Journal of Pharmaceutical Sciences 2008;1(1\&2):85-88.

[57] Zachariah S, Viswanad V, Aleykutty NA, Jaykar B and Halima OA. Free radical scavenging and antibacterial activity of Mirabilis jalapa Linn using in vitro models.Asian J Pharm Clin Res 2012; 5(3):115-120.

[58] Hajji M, Jarraya R, Lassoued I, Masmoudi O, Damak M and Nasri M. GC/MS and LC/MS analysis, and antioxidant and antimicrobial activities of various solvent extracts from Mirabilis jalapa tubers. Process Biochemistry 2010; 45:1486-1493.

[59] Zachariah SM, Aleykutty NA, Viswanad V, Jacob S and Prabhakar V. In vitro antioxidant potential of methanolic extracts of Mirabilis jalapaLinn. Free Radicals and Antioxidants 2011; 1(4):82-86.

[60] Gogoi J, Nakhuru KS, Chattopadhayay P, Kumar Rai A and Veer V. Hypertrophic scar formation on application of terpenoid fraction of tuberous root of Mirabilisjalapa L on excision wound model in Wistar albino rats.IntSch Res Notices 2014: 583730.doi: 10.1155/2014/583730

[61] Vazir M, Bindhu K, Kalaikovan T and Subedi A. Evaluation of wound healing activity of leaves of Mirabilis jalapaL in experimentally induced diabetic rats. ICJPIR 2016; 3(1): 95-98.

[62] Zullies I, Kawati S and Sismindari. Cytotoxicity against tumor cell lines of a ribosome - inactivating protein (RIP) like protein isolated from leaves of Mirabilis jalapaL. Malays J Pharm Sci 2006; 4(1):31-41.

[63] Zullies I Sudjadi, Widyaningsih E, Dyah P and Sismindari. Induction of apoptosis by protein fraction isolated from the leaves of Mirabilis jalapaL on HeLa and Raji cell-line. Oriental Pharmacy and Experimental Medicine 2003; 3(3):151-156.

[64] Kale DKC and Mukundan U. Cytotoxicity against tumor cell lines of a purified Mirabilis antiviral protein isolated from root of Mirabilis jalapa. World Journal of Pharmaceutical Research 2015;4(2):1696-1710.

[65] Watthanachaiyingcharoen R, Utthasin P, Potaros T and Suppakpatana P. Proteins from Mirabilis jalapapossess anticancer activity via an apoptotic pathway. J Health Res 2010; 24(4):161-165.

[66] Ikawati Z, Sudjadi EW, Puspitasari D and Sismindari. Induction of apoptosis by protein fraction isolated from the leaves of Mirabilis jalapaL on HeLa and Raji cell-line. Oriental Pharm Exp Med 2003; 3(3):151-156.

[67] Ikawati Z, Sudjadi and Sismindari. Cytotoxicity against tumor cell lines of a ribosome-inactivating protein (Rip)like protein isolated from leaves of Mirabilis jalapa L. Malaysian J Pharm Sci 2006; 4(1):31-41.

[68] Nath LR, Manjunath KP, Savadi RV and Akki KS. Anti-inflammatory activity of Mirabilis jalapa Linn. leaves. J Basic Clin Pharm 2010;1(2):93-96.

[69] Singh M, Kumar V, Singh I, Gauttam V and Kalia AN. Anti-inflammatory activity of aqueous extract of Mirabilis jalapa Linn leaves. Pharmacognosy Res 2010; 2(6):364-367. 
[70] Augustine B, Dash S, Lahkar M, Lihite RJ, Samudrala PK and Pitta S. Effect of Mirabilis jalapa Linn flowers in experimentally induced arthritis and consecutive oxidative stress. International Journal of Pharmacy and Pharmaceutical Sciences 2013; 5(2):190-193.

[71] Walker CI, Trevisan G, Rossato MF, Silva CR, Pinheiro FV, Franciscato C, Tatsch E, Moretto MB, Silva MD, Manfron MP, NoalMoresco R, Santos AR, Pereira ME and Ferreira J. Antinociceptive effect of Mirabilis jalapa on acute and chronic pain models in mice. J Ethnopharmacol 2013;149(3):685-693.

[72] Walker CI, Trevisan G, Rossato MF, Franciscato C, Pereira ME, Ferreira J and Manfron MP. Antinociceptive activity of Mirabilis jalapa in mice. J Ethnopharmacol 2008; 120(2):169-175.

[73] Zhou JY, Zhou SW, Zeng SY, Zhou JY, Jiang MJ and He Y. Hypoglycemic and hypolipidemic effects of ethanolic extract of Mirabilis jalapa L root on normal and diabetic mice. Evid Based Complement Alternat Med 2012; 2012:257374. doi: 10.1155/2012/257374.

[74] Victor AD, Sowndarya R and Moorthi N. Anti diabetic activity of hydroethanolic extracts of Mirabilis jalapa leaves in streptozotocin induced diabetic rats. IJPPR Human2015; 4(2):331-338.

[75] Maxia A, Sanna C, Salve B, Kasture A and Kasture S. Inhibition of histamine mediated responses by Mirabilis jalapa: confirming traditional claims made about antiallergic and antiasthmatic activity. Nat Prod Res 2010; 24(18):1681-1686.

[76] Aoki K, Cortés AR, RamírezMdel C, Gómez-Hernández M and López-Muñoz FJ. Pharmacological study of antispasmodic activity of Mirabilis jalapa Linn flowers. J Ethnopharmacol 2008;116(1):96-101. 